\title{
Properties of Waste Tire Rubber Powder
}

\author{
Melik Bekhiti \\ Civil Engineering Department, Djillali \\ Liabes University of Sidi Bel Abbes, \\ Algeria \\ bkheti.melik@yahoo.fr
}

\author{
Habib Trouzine \\ Civil Engineering Department, Djillali \\ Liabes University of Sidi Bel Abbes, \\ Algeria \\ h_trouzine@yahoo.fr
}

\author{
Aissa Asroun \\ Civil Engineering Department, Djillali \\ Liabes University of Sidi Bel Abbes, \\ Algeria \\ a_asroun@yahoo.fr
}

\begin{abstract}
Scrap tires are abundant and alarming waste. The aggregates resulting from the crushing of the waste tires are more and more used in the field of civil engineering (geotechnical, hydraulic works, light concretes, asphaltic concretes, etc.). Depending on the type of the used tires, dimensions and possible separations and treatment, the physical and mechanical characteristics of these aggregates might change. Some physical, chemical and direct shear tests were performed on three gradation classes of waste tire rubber powder. The tests results were combined with data from previous studies to generate empirical relationships between cohesion, friction angle and particle size of waste tire powder rubber. A cubic (third order) regression model seems to be more appropriate compared to linear and quadratic models.
\end{abstract}

Keywords-rubber powder; waste tires; experimental; polynomial regression

\section{INTRODUCTION}

In recent decades, the worldwide growth of the automobile industry and the increasing use of cars as the main means of transport have tremendously boosted tire production. This has generated massive stockpiles of used tires. Extensive research projects were carried out on how to use used tires in different applications [1]. The scrap tires in Algeria are estimated at approximately 25,918 tones/year [2].Waste tires need a larger storage space than other waste due to their large volume and fixed shape. They are unlikely to be decomposed, as burying the waste tires would shorten the service life of the burial ground and have low economic benefit; In addition, buried waste tires often emerge from the burial ground surface or destroy the anti-leakage cover of the burial ground and the exposed waste tires accumulate water that may breed bacteria, molds, insects or mice. In case of fire, waste tires generate toxic gases, such as dioxin, that could result in severe pollution problems [3-4].

In order to properly dispose these millions of tires, the use of innovative techniques to recycle them is important. The use of scrap tires including tire chips or tire shreds comprised of pieces of scrap tires, tire chip/soil mixtures, tire sidewalls, and whole scrap tires in civil engineering applications is the object of the standard ASTM D 6270. These materials can be used in lightweight embankment fill, lightweight retaining wall backfill, drainage layers, thermal insulation to limit frost penetration beneath roads, insulating backfill to limit heat loss from buildings, and replacement for soil or rock in other fill applications [5].

Rubber tires can also be used in civil and non-civil engineering applications such as in road construction, in geotechnical works, as a fuel in cement kilns and incineration for production of electricity or as an aggregate in cement-based products or in geotechnical field [6-7-8].

ASTM D 6270 studied the properties of shredded waste tires (Practical size of $2 \mathrm{~mm}$ and more), but not waste tire rubber powder. The objective of this paper is to present experimental work on the waste tire rubber powder. Further, a polynomial regression analysis of the cohesion and friction angle versus the particles size is proposed.

\section{MATERIALS AND METHODS}

\section{A. Tire rubber powder}

Scrap tire rubber powder can be obtained from tires through two principal processes: (1) ambient, which is a method in which scrap tire rubber is ground or processed at or above ordinary room temperature and (2) cryogenic, a process that uses liquid nitrogen to freeze the scrap tire rubber until it becomes brittle and then uses a hammer mill to shatter the frozen rubber into smooth particles [9]. For this study, the rubber powder was produced from three used automobile tires by mechanical shredding at ambient temperature. Steel was removed by magnetic separation and one part of textile fiber was removed by density. A photograph of the used scrap tire rubber sample is shown in Figure 1.

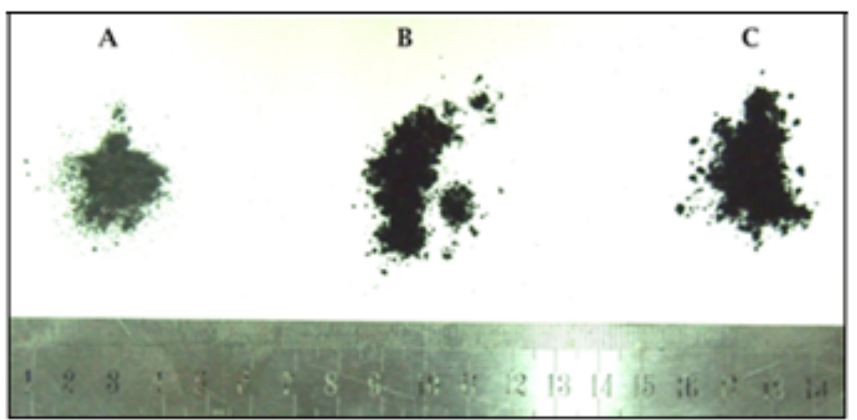

Fig. 1. Used rubber powder. A less than $0.08 \mathrm{~mm}, \mathrm{~B}$ size of $1 \mathrm{~mm}$ and $C$ size of $1.6 \mathrm{~mm}$. 


\section{B. Physical Characteristics of the Rubber Powder}

The used specimens don't contain steel but contain less than $2 \%$ of textile fiber. Since it was not possible to determine the gradation curve of the rubber powder as for normal aggregates, a microscope examination was done. Dimensions of rubber powder vary from $1.6 \mathrm{~mm}$ to $0.8 \mathrm{~mm}$ with an average particle size of $1 \mathrm{~mm}$. The density of the rubber powder is determined using helium pycnometer and it's about 0.83 . Rubber powder is also characterized by an insignificant water absorption less than 3\%.Table I resumes some characteristics of the used waste tire powder rubber.

TABLE I. RUBBER POWDER CHARACTERISTICS

\begin{tabular}{|c|c|}
\hline Properties & Rubber powder \\
\hline Density & 0.83 \\
\hline Size & $80 \mu \mathrm{m}-1.6 \mathrm{~mm}$ \\
\hline Elongation (\%) & 420 \\
\hline Rate of steel fiber & $0 \%$ \\
\hline
\end{tabular}

\section{Chemical analysis}

The tire is made up mainly by rubber. Its constitution varies a little between the car tires and heavy truck tires. Rubber consists of a complex mixture of elastomers, polyisoprene, polybutadiene and stirene-butadiene. Stearic acid (1.2\%), zinc oxide (1.9\%), extender oil (1.9\%) and carbon black (31.0\%) are also important components of tires [10-11]. In Table II, chemical composition of the used rubber powder is presented. The quantity of steel is generally about $15 \%$, and it's more important for the heavy trucks tires. For this study steel and one part of textile were removed by magnetic separation and density.

TABLE II. RUBBER POWDER CHARACTERISTICS

\begin{tabular}{|c|c|}
\hline Material/element & Mass percentage \\
\hline Rubber & $54 \%$ \\
\hline Carbon black & $29 \%$ \\
\hline Textile & $2 \%$ \\
\hline Oxidize zinc & $1 \%$ \\
\hline Sulfur & $1 \%$. \\
\hline Additives & $13 \%$ \\
\hline
\end{tabular}

\section{Direct Shear Test}

The tests were performed according to ASTM D 3080 standard [12]. The direct shear test is a laboratory testing method used to determine the shear strength parameters of rubber powder. To achieve reliable results, the test is often carried out on three or four samples of rubber powder. The sample is placed in a shear box for round specimens $(60 \mathrm{~mm}$ diameter and $20 \mathrm{~mm}$ height). The shear box is composed of an upper and lower box. The limit between the two parts of the box is approximately at the mid height of the sample. The sample is subjected to a controlled normal stress and the upper part of the sample is pulled laterally at a controlled strain rate or until the sample fails. The applied lateral load and the induced strain are recorded at given internals.

These measurements are then used to plot the stress-strain curve of the sample during the loading for the given normal stress. Results of different tests for the same rubber powder are presented in figures with peak stress on the horizontal axis and normal (confining) stress on the vertical axis. A linear curve fitting is often made on the test result points. The intercept of this line with the vertical axis gives the cohesion and its slope gives the peak friction angle.

\section{E. Preparation of test specimens}

For practical consideration, specimens were separated to three gradation classes. Class A: less than $0.08 \mathrm{~mm}$, class B: size between $1.6 \mathrm{~mm}$ and $1 \mathrm{~mm}$ and class $\mathrm{C}$ : size more than 1.6 $\mathrm{mm}$

\section{F. Tests}

The specimens are round (60 mm diameter and $20 \mathrm{~mm}$ high). The realized test is an unconsolidated un-drained test (UU). The normal constraints (normal stress) used are: 100, 200 and $300 \mathrm{kPa}$. The speed of shearing is about $0.5 \mathrm{~mm} / \mathrm{min}$. The sample is placed between two half-boxes that can move relatively to each other. Moreover, a piston permits to exert a normal constraint in the plan of shearing. The inferior half-box is involved horizontally at a constant speed. The total force of shearing $\mathrm{F}$ is to be measured using a fixed ring at the superior half-box.

\section{RESULTS AND DISCUSSION}

Figure 2 presents the results of the shear strength tests (curve intrinsic), the cohesion and the internal friction angle of the waste tire rubber powder, value relatively important if compared to some experimental values of the literature.

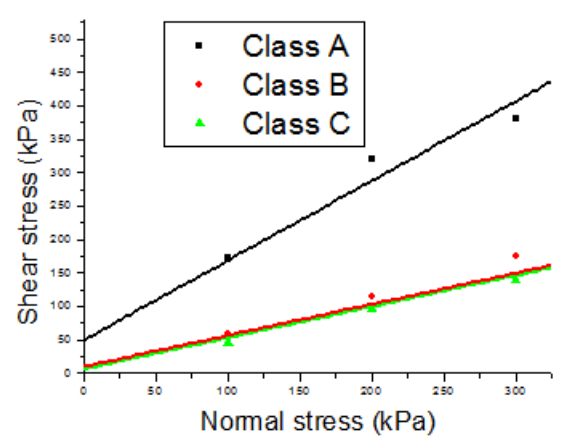

Fig. 2. Direct Shear Tests of rubber powder.

The waste tire rubber powder is strongly compressible, moreover the surface quality of the powder produced by mechanical crushing with ambient temperature is irregular. The Mohr-Coulomb shear strength parameters obtained from direct shear tests by these studies are presented in (1).

$$
\begin{aligned}
& \tau=c+\operatorname{tg} \varphi \\
& \text { Class } A: \tau=6.5+\operatorname{tg} 25^{\circ} \\
& \text { Class } B: \tau=10+\operatorname{tg} 25^{\circ} \\
& \text { Class } C: \quad \tau=50+\operatorname{tg} 8^{\circ}
\end{aligned}
$$

It's observed that the cohesion values vary from 6.5 to 50 $\mathrm{kPa}$, and fewer values were observed for class A and B sizes. 
Friction angles vary from 8 to $25^{\circ}$ and it's increasing with particle size.

\section{POLYNOMIAL REGRESSION}

The following table gives values of cohesion $C$ and friction angle $\varnothing$ according to the average size of the rubber particles $T$ according to the literature [10-11-13-16-17] and this work.

TABLE III. EXPERIMENTAL RESULTS

\begin{tabular}{|c|c|c|c|c|}
\hline References & Size $(\mathrm{mm})$ & $C(k P a)$ & $\varnothing\left({ }^{\circ}\right)$ & Conditions of test \\
\hline \multirow{3}{*}{$\begin{array}{l}\text { Black and } \\
\text { Shakoor, } \\
1994 \text { [10] }\end{array}$} & $<1.06$ & 4.78 & 30 & \multirow{3}{*}{ Dry density about 0.33} \\
\hline & $1.016-4.064$ & 3.3516 & 31 & \\
\hline & 4.064-6.858 & 6.224 & 27 & \\
\hline \multirow{2}{*}{$\begin{array}{c}\text { Benda } 1995 \\
{[11]}\end{array}$} & 2 & 0 & 25.8 & \multirow{2}{*}{$\begin{array}{l}\text { Rate of deformation } 10 \% \\
\text { Rate of deformation } 20 \%\end{array}$} \\
\hline & 2 & 0 & 36 & \\
\hline $\begin{array}{c}\text { Massad et al, } \\
1996 \text { [13] }\end{array}$ & 4.572 & 81.97 & 15 & Rate of deformation $20 \%$ \\
\hline $\begin{array}{l}\text { Wu et al, } \\
1997[14]\end{array}$ & 2 & 0 & 45 & No steel fiber \\
\hline $\begin{array}{c}\text { Bekhiti et al } \\
2012 \text { [15] }\end{array}$ & 0.405 & 77 & 8.5 & No steel fiber \\
\hline \multirow{3}{*}{$\begin{array}{c}\text { Present } \\
\text { work }\end{array}$} & 1.6 & 6.5 & 25 & \multirow{3}{*}{ No steel fiber } \\
\hline & 1 & 10 & 25 & \\
\hline & 0.08 & 50 & 8 & \\
\hline
\end{tabular}

The graph in double y of Figure 3 represents the principal results of $C$ and $\varnothing$ according to the average particles sizes according to the literature and this work.

The values of cohesion vary from 0 to $81.97 \mathrm{kPa}$, for the friction angle the values vary from 8.5 to $45^{\circ}$. In order to estimate a relations ships among variables (T, $C$ and $\varnothing$ ), polynomial regressions analysis of $C$ versus $T$ and $\varnothing$ versus $T$ using linear, quadratic and cubic models were used. Only results of cubic models will be presented here, since coefficients of determination seems to be interesting.

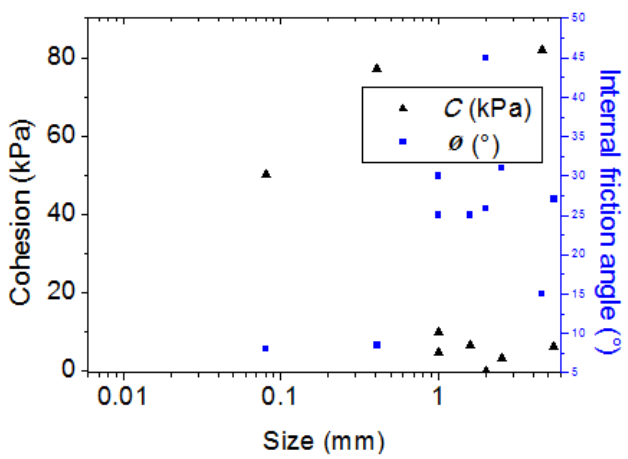

Fig. 3. Values the angle internal fraction and the cohesion according to decimal logarithm of the average size of waste tire rubber particle according to the literature and this work.

\section{A. Variation of cohesion according to the rubber powder particle size}

The cubic model gives a rather faithful image of the situation compared to the linear and quadratic ones. The polynomial regression using cubic model is given by (2), with $\mathrm{S}=21.0599$, and R-Sq (multiple coefficient of determination) =
72.3\%. R-Sq (adjusted) value is about 58.4\%. The fitted line plot is presented in Figure 4.

$$
C=87.25-132.4 T+59.22 T^{2}-6.48 T^{3}
$$

where $\mathrm{C}$ : the cohesion $(\mathrm{kPa})$ and $\mathrm{T}$ : the particle size in $(\mathrm{mm})$.

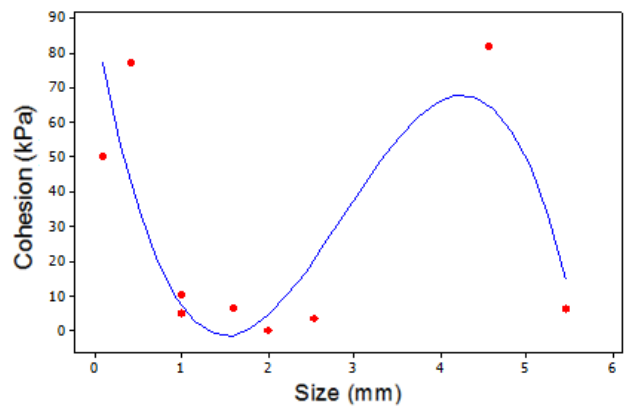

Fig. 4. Fitted line plot of cohesion versus particle size.

B. Variation of friction angle according to the rubber powder particle size

For friction angle versus particle size, the polynomial regression using cubic model is given by (3), with $S=5.186$, and R-Sq (multiple coefficient of determination) $=80.1 \%$. RSq (adjusted) value is about $70.2 \%$. The fitted line plot is presented in Figure 5. The regression for this case is more representative than for $C$ versus $T$.

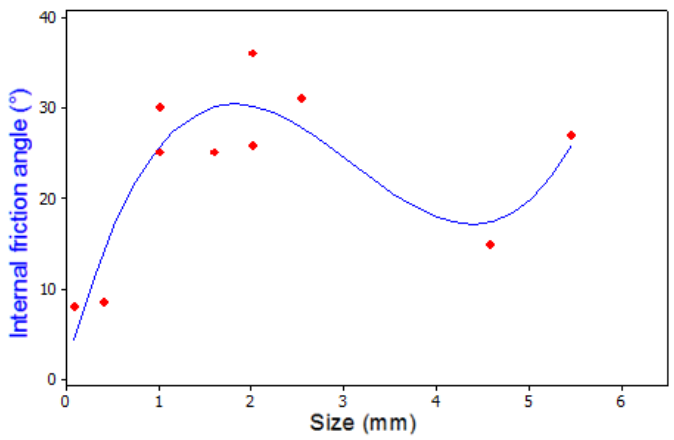

Fig. 5. Fitted line plot of internal friction angle versus particle size..

$$
\varphi=1.557+36.90 T-14.39 T^{2}+1.548 T^{3}
$$

where: Ø: friction angle in $\left(^{\circ}\right)$; T: the particle size in $(\mathrm{mm})$.

\section{CONCLUSION}

Waste tire rubber powder is used in a variety of civil and non-civil engineering applications. Some properties of rubber powder resulting from crushing of light vehicles waste tires with no steel fiber have been determined in this work: the particle size, the density, the chemical composition as well as the cohesion and friction angle by direct shear test. Rubber powder, crushed mechanically in ambient temperature, showed 
has a very low density of about 0.83 , cohesion varied from 6.5 to $50 \mathrm{kPa}$. Friction angle varied from 8 to $25^{\circ}$ according to the average size rubber particle. Using the results from this study along with previous results from other studies, cubic regressions is proposed. Cohesion as well as friction angle versus particle size using cubic model give respectively for the coefficient of determination values of 72.3 and $80.1 \%$.

\section{REFERENCES}

[1] E. Ganjian, M. Khorami, A. A. Maghsoudi, "Scrap-tyre-rubber replacement for aggregate and filler in concrete”, Construction and Building Materials, Vol. 23, No. 5, pp. 1828-1836, 2009

[2] H. Trouzine, A. Asroun, N. Asroun, F. Belabdelouhab, N.T. Long, "Problem of waste tires in Algeria", Nature \& Technologies, Vol. 5, pp. 28-35, 2011[In French]

[3] Rubber Manufacturer's Association, US scrap tire markets 2003 edition, Washington (DC), Rubber Manufacturer's Association, 2004

[4] R.K. Dhir, M.C. Limbachiya, K.A. Paine, Recycling and reuse of used tyres, Thomas Telford Publishing-Thomas Telford Ltd, London, 2001

[5] ASTM D 6270-98 (Reapproved 2004), Standard practice for use of scrap tires in civil engineering applications, ASTM International, West Conshohocken, USA

[6] V. Corinaldesi, G. Moriconi, "Durable fiber reinforced selfcompacting concrete", Cement and Concrete Research, Vol. 34, No. 2, pp. 249-254, 2004

[7] V. Corinaldesi, A. Mazzoli, G. Moriconi, "Mechanical behaviour and thermal conductivity of mortars containing waste rubber particles”, Materials \& Design, Vol. 32, No. 3, pp. 1646-1650, 2011

[8] H. Trouzine, M. Bekhiti, A. Asroun, "Effects of scrap tyre rubber fibre on swelling behavior of two clayey soils in Algeria”, Geosynthetics International, Vol. 19, No. 2, pp. 124-132, 2012
[9] California Department of Transportation, Asphalt rubber usage guide, Caltrans, State of California, Department of Transportation, Sacramento, CA, USA, 2003

[10] B.A Black, A. Shakoor, “A geotechnical investigation of soil/tire mixtures for engineering applications”, Proceedings on the First International Conference on Environmental Geotechnics, pp. 617623, 1994

[11] C. C. Benda, "Engineering properties of scrap tires used in geotechnical applications”, Report $\mathrm{N}^{\circ}$ 95-1, Vermont Agency of Transportation, Montpelier, V.T., 1995

[12] ASTM D 3080-03 Standard Test Method for Direct Shear Test of Soils Under Consolidated Drained Conditions, ASTM International, West Conshohocken, USA

[13] E. Massad, R. Taha, C. Ho, T. Papagiannakis, "Engineering properties of tire /soil mixtures as a lightweight fill material", Geotechnical Testing Journal, Vol. 19, No. 3, pp. 297-304, 1996

[14] W. Y. Wu, C. C. Benda, R. F. Cauley, "Triaxial determination of shear strength of tire chips", Journal of Geotechnical and Geoenvironmental Engineering, Vol. 123, N. 5, 479-482, 1997

[15] M. Bekhiti, H. Sellaf, H. Trouzine A. Asroun, "Propriétes mécaniques des granulats de caoutchouc issus du broyage des pneus uses”, 1st International Conference on Civil Engineering, 8-9 may 2012, Laghouat Algeria [in French] 